\title{
BUFFEL GRASS MORPHOAGRONOMIC CHARACTERIZATION FROM Cenchrus GERMPLASM ACTIVE BANK ${ }^{1}$
}

\author{
LEILA REGINA GOMES PASSOS BRUNO ${ }^{2 *}$, RAFAELA PRISCILA ANTONIO ${ }^{3}$, JOSÉ GERALDO DE AQUINO \\ ASSIS $^{4}$, JOSÉ NILTON MOREIRA ${ }^{3}$, IRLANE CRISTINE DE SOUZA ANDRADE LIRA ${ }^{5}$
}

\begin{abstract}
This study aimed to characterize buffel grass accessions of the Cenchrus Germplasm Active Bank (CGAB) from Embrapa Semi-Arid in a morphoagronomic way, checking the descriptors variability and efficiency in accessions on two consecutive cuts. Twenty-five accessions and five buffel grass cultivars were used in randomized complete block design with three replications. Evaluations were conducted after two consecutive cuts, each evaluation performed 90 days after each cut. Characterization was based on 15 quantitative and qualitative morphoagronomic descriptors. Quantitative descriptors were subjected to individual and joint univariate analysis of variance, followed by the Scott-Knott's test at 5\% significance. Yet qualitative descriptors were submitted to descriptive analysis. Both quantitative and qualitative descriptors were grouped based on the Gower algorithm for divergence analysis. A dendrogram and calculations of the characters relative importance for divergence were established. Genotype and cutting effects were significant for almost all descriptors in the joint analysis. This result indicates a genetic variability between genotypes and, regarding the cut, it indicates mainly differences in growth rate of each genotype in each cutting season. Genotypes were separated into three groups, which showed good genotype variation. The number of tillers per clump, followed by number of inflorescence and color of seeds, were the most relevant characters in genotype separation.
\end{abstract}

Keywords: Genetic resources. Genetic diversity. Forage grasses. Genotypes x environments interaction.

\section{CARACTERIZAÇÃO MORFOAGRONÔMICA DE CAPIM BUFFEL DO BANCO ATIVO DE GERMOPLASMA DE Cenchrus}

RESUMO - O estudo objetivou caracterizar morfoagronomicamente acessos de capim buffel do Banco de Germoplasma de Cenchrus (BGC) da Embrapa Semiárido, verificando a variabilidade e eficiência dos descritores nos acessos em dois cortes consecutivos. Foram utilizados 25 acessos e cinco cultivares de capim buffel em delineamento em blocos casualizados completos com três repetições. As avaliações foram realizadas após dois cortes consecutivos, cada avaliação foi realizada 90 dias após cada corte. A caracterização foi realizada com base em 15 descritores morfoagronômicos quantitativos e qualitativos. Os descritores quantitativos foram submetidos a análise de variância univariada individual e conjunta e, em seguida, aplicado o teste de Scott-Knott a 5\% de significância. Os descritores qualitativos foram submetidos a análise descritiva. Para as análises de divergência tanto descritores quantitativos quanto qualitativos foram agrupados com base no algoritmo de Gower. Foi estabelecido também um dendrograma e calculada a importância relativa dos caracteres para a divergência. $\mathrm{Na}$ análise conjunta, os efeitos de genótipo e corte foram significativos para quase todas os descritores. Esse resultado indica variabilidade genética entre os genótipos e quanto ao corte indica, principalmente, diferenças na velocidade de crescimento de cada genótipo em cada época de corte. Os genótipos foram separados em três grupos demonstrando boa variabilidade entre os genótipos. O número de perfilhos por touceira, seguida por quantidade de inflorescência e cor das sementes foram os caracteres de maior relevância na separação dos genótipos.

Palavra-chave: Cenchrus ciliaris. Recursos genéticos. Diversidade genética. Gramíneas forrageiras. Interação genótipos $\mathrm{x}$ ambientes.

\footnotetext{
*Corresponding author

${ }^{1}$ Received for publication in $05 / 07 / 2015$; accepted in $08 / 23 / 2016$

Paper extracted from the master dissertation of the first author.

${ }^{2}$ Postgraduate Program in Plant Genetic Resources, Universidade Estadual de Feira de Santana, Feira de Santana, BA, Brazil; leilargpbruno@hotmail.com.

${ }^{3}$ Embrapa Semiárido, Petrolina, PE, Brazil; rafaela.antonio@embrapa.br, jose.moreira@embrapa.br.

${ }^{4}$ Department of Biology, Universidade Federal da Bahia, Salvador, BA, Brazil; jgaassis@ufba.br.

${ }^{5}$ Postgraduate Program in Agronomy, Universidade Federal Rural de Pernambuco, Recife, PE, Brazil; irlane.cristine@gmail.com.
} 


\section{INTRODUCTION}

Buffel grass (Cenchrus ciliaris L.) is a drought tolerant forage widely grown in dry tropical and subtropical regions worldwide. It owns a permanent and deep root system, able to withstanding heavy grazing, with high nutritional value for cattle and sheep, and fast response to moisture, when available (MARSHALL; LEWIS; OSTENDORF, 2012; BURSON et al., 2015). This grass is suited to grow in disturbed areas, showing rapid growth and maturation, prolonged flowering and prolific seeding (MARTIN et al., 2015). Thus, it is one of the most suitable forage grasses for the Northeastern semiarid of Brazil; therefore, exploiting its germplasm, or of species from the same genus, may contribute to selection of genotypes with foraging potential, customized to these regional climatic conditions.

However, for using its genetic resources in breeding programs, it is necessary the conserved germplasm to be characterized and evaluated for estimates of variability or genetic diversity available. This step is essential so that breeders can make good decisions in choosing one genetic material.

Morphological characterization is one of the steps to access genetic diversity, both between and within plant accessions, providing early estimates on existing variability, since it is made on observations and measurements of various easily detectable phenotypic descriptors (BURLE; OLIVEIRA, 2010). Subsequently, finer characterizations are performed through cytogenetic techniques, DNA markers, among others. Thus, morphological characterization is important to differentiate genotypes into germplasm collections or banks, and as an assisting tool in genetic improvement programs. This type of characterization is also important to reduce costs of germplasm maintenance, by removing duplicates, sometimes from multiple inputs, or disparate accessions from heterogeneous samples, which would result in progeny segregation and failure to original genotype maintenance.

Genetic diversity can be assessed by one specific method or by a combination of them. Data often involve numerical measures, i.e. quantitative variables (number of tillers per clump and inflorescences, number of days from emergence to flowering) and/or qualitative variables distributed discontinuously, splitting phenotypic classes highly distinct and separable from one another (leaf color, hairiness, growth pattern). Once there is a set of data involving both quantitative and qualitative variables, a joint analysis of the variables may highlight the diversity in germplasm bank accurately (MOURA et al., 2010).

The Cenchrus Germplasm Active Bank of Embrapa Semi-Arid has about 120 accessions from different Embrapa units, foreign institutions and collections made in Paraíba, Pernambuco, Bahia, Sergipe and São Paulo states (SILVA et al., 2010). These sources have been characterized and evaluated over the years (ANTONIO et al., 2015). However, there is no information on the performance of these accessions after successive cuts.

Given that, the purpose of this study was to characterize buffel grass accessions from the Cenchrus Germplasm Active Bank of Embrapa Semi -Arid, both morphologically and agronomically, checking variability and efficiency of descriptors in accessions after two consecutive cuts.

\section{MATERIAL AND METHODS}

This research was carried out in the Caatinga Experimental Station, which belongs to Embrapa Semi-Arid, Petrolina-PE, Brazil. The area lies at the geographical coordinates of $09^{\circ} 09^{\prime}$ South latitude, $40^{\circ} 22^{\prime}$ West longitude, and altitude of $365.5 \mathrm{~m}$. Local soil is classified as Red-yellow Argisol (Ultisol), with medium texture (SANTOS et al., 2006). In this study, we used 30 genotypes from Cenchrus Germplasm Active Bank of Embrapa Semi-Arid, shown in Table 1. These accessions remained in cold storage at $10^{\circ} \mathrm{C}$ and $40 \%$ relative humidity.

Table 1. Identification and origin of 30 Cenchrus sp. genotypes from the Cenchrus Germplasm Active Bank of Embrapa Semi-Arid, characterized and evaluated from quantitative and qualitative descriptors.

\begin{tabular}{rccc}
\hline Genotypes & $\begin{array}{c}\text { Identification code in the } \\
\text { CGAB }\end{array}$ & $\begin{array}{c}\text { Date of } \\
\text { introduction }\end{array}$ & Origin \\
\hline 3 & POA-03 & $03 / 06 / 2014$ & Petrolina-PE \\
5 & POA-04 & $03 / 06 / 2014$ & Petrolina-PE \\
6 & POA-06 & $03 / 06 / 2014$ & Petrolina-PE \\
40 & POA-40 & $03 / 06 / 2014$ & Petrolina-PE \\
52 & 7752 & $03 / 14 / 1977$ & Matão-SP (IRI) \\
119 & 79119 & $03 / 06 / 1979$ & Índia (IARI) \\
123 & 79123 & $04 / 07 / 1979$ & Austrália (CSIRO) \\
138 & 79138 & $06 / 26 / 1979$ & Quissamã-SE \\
141 & 79141 & $06 / 26 / 1979$ & Quissamã-SE \\
158 & 79158 & $06 / 26 / 1979$ & Quissamã-SE \\
195 & 80195 & $05 / 11 / 1980$ & Tanzânia (Cenargen) \\
198 & 80198 & $05 / 11 / 1980$ & Tanzânia (Cenargen) \\
237 & POA-237 & $03 / 06 / 2014$ & Petrolina-PE \\
\hline
\end{tabular}


L. R. G. P. BRUNO et al.

Table 1. Continuation.

\begin{tabular}{cccc}
\hline Genotypes & $\begin{array}{c}\text { Identification code in the } \\
\text { CGAB }\end{array}$ & $\begin{array}{c}\text { Date of } \\
\text { introduction }\end{array}$ & Origin \\
\hline 302 & 82302 & $01 / 11 / 1982$ & Irã \\
433 & 83433 & $06 / 28 / 1983$ & Austrália (CSIRO) \\
434 & 83434 & $06 / 28 / 1983$ & Austrália (CSIRO) \\
541 & 87541 & $06 / 12 / 1987$ & Kênia (NARS) \\
571 & 90571 & $09 / 10 / 1990$ & USA (Texas A\&M) \\
572 & 90572 & $09 / 10 / 1990$ & USA (Texas A\&M) \\
579 & 90579 & $09 / 10 / 1990$ & USA (Texas A\&M) \\
585 & 90585 & $09 / 10 / 1990$ & USA (Texas A\&M) \\
592 & 90590 & $09 / 10 / 1990$ & USA (Texas A\&M) \\
598 & 90598 & $09 / 10 / 1990$ & USA (Texas A\&M) \\
603 & 90603 & $09 / 10 / 1990$ & USA (Texas A\&M) \\
617 & 90617 & $09 / 10 / 1990$ & USA (Texas A\&M) \\
CPATSA 7754 & 7754 & $03 / 14 / 1977$ & Matão-SP (IRI) \\
Áridus & 80196 & $05 / 11 / 1980$ & Tanzânia (Cenargen) \\
Biloela & 7602 & $02 / 26 / 1976$ & Pernambuco (Agroceres) \\
Gayndah & 7603 & $02 / 26 / 1976$ & Pernambuco (Agroceres) \\
Grei & 79176 & $11 / 19 / 1979$ & Bahia \\
\hline
\end{tabular}

The study was conducted from July 30 of 2013 to April 30 of 2014. Ten seeds from each accession were sown directly in field previously plowed, harrowed, and irrigated by dripping. The analyses were performed in randomized complete block design, with three replicates of nine plants; each plot comprised one accession. Plants were spaced $1.00 \mathrm{~m}$ between rows and $0.50 \mathrm{~m}$ within plants. The central plant of each plot was considered as the focal plant; plots were 2 meters apart from another to avoid intergenotypic competition.

Ninety days after sowing, plants were cut at $10 \mathrm{~cm}$ from the ground for standardization. According to Bhering et al. (2008), this mowing height is required to improve forage quality and yield at harvest time. Descriptor evaluation began three months after standardization cut, and extended up to plant flowering. The second evaluation was carried out three months after second cut.

We used quantitative and qualitative descriptors used by Jorge et al. (2008), with modifications. The quantitative ones were: a) number of tillers per clump (NTC), plants were cut at $10 \mathrm{~cm}$ height, then tillers were counted; b) plant height $(\mathrm{PH})$ in $\mathrm{cm}$, clump was tied and measured from the ground to top leaf height, with the aid of a measuring tape; c) stem thickness (ST) in $\mathrm{mm}$, measured by the average stem diameter above the lowest node, with the aid of a digital caliper; d) leaf length (LL) in $\mathrm{mm}$, measured from ligule to leaf apex, with a graduated ruler; e) leaf width (LW) in $\mathrm{mm}$, taken at the widest leaf point, with a graduated ruler; f) inflorescence length (IL) in $\mathrm{cm}$, with the aid of a digital caliper; g) inflorescence width (IW) in $\mathrm{cm}$, with the aid of a digital caliper; $\mathrm{h}$ ) number of inflorescences (NI) per plant. The qualitative descriptors were based on a grading scale, as follows: a) growth habit $(\mathrm{GH})$ : 1 - prostrate, 2 - semi-prostrate and 3 - upright; b) leaf color (LC): 1 - light green, 2 - dark green, 3 - purple, and 4 - other colors; c) adaxial leaf hairiness (LH1):
1 - without trichomes, 2 - with a few trichomes and 3 - with many trichomes; d) abaxial leaf hairiness (LH2): 1 - without trichomes; 2 - with few trichomes; 3 - with many trichomes; e) leaf sheath hairiness (LH3): 1 - without trichomes, 2 - with few trichomes and 3 - with many trichomes; f) inflorescence color (IC): 1 - cream, 2 - purple and 3 other color; g) seed color (SC): 1 - cream; 2 - purple and 3 - other color.

Quantitative data were submitted to individual and joint analysis of variance. The joint analysis shows data from each descriptor after each cut. Mean square decomposition was used to estimate simple and complex interactions, using expression proposed by Cruz and Castoldi (1991). Then, the Scott-Knott's test was applied at 5\% significance level. Data of each quality descriptor underwent descriptive analysis.

To quantify genetic divergence among accessions, means of quantitative and qualitative descriptors of the two consecutive cuts were used. The Gower algorithm (1971) estimated the joint analysis distance matrix for qualitative and quantitative descriptors. In this method, distance matrix values range between 0 and 1 , and standardization of quantitative and qualitative variables was necessary, being expressed by:

$$
S_{i j}=\frac{\sum_{k=1}^{p} W i j k . S i j k}{\sum_{k=1}^{p} W i j k}
$$

$\mathrm{K}=$ number of variables $(\mathrm{k}=1,2, \ldots \mathrm{p})$; $\mathrm{p}=$ total number of evaluated characteristics; $i$ and $\mathrm{j}=$ any two individuals; $\mathrm{W}_{\mathrm{ijk}}=$ weight given $\mathrm{ijk}$ comparison, assigning value 1 for valid comparisons, and 0 for invalid comparisons (when the variable value is missing in one or both individuals); $\mathrm{S}_{\mathrm{ijk}}=$ variable $\mathrm{k}$ contribution in similarity between individuals $i$ and $j$ with values between 0 and 1 . For a qualitative variable (nominal), if the value of variable $\mathrm{k}$ is the same for both individuals and, $\mathrm{i}$ and 
$\mathrm{j}$, then Sijk $=1$, otherwise, it equals 0 ; for a quantitative variable (continuous) $\mathrm{S}_{\mathrm{ijk}}=1-\left|\mathrm{x}_{\mathrm{ik}}-\mathrm{x}_{\mathrm{jk}}\right| / \mathrm{R}_{\mathrm{k}}$, where $\mathrm{x}_{\mathrm{ik}}$ and $\mathrm{x}_{\mathrm{jk}}$ are the values of variable $k$ for individuals $i$ and $j$, respectively, and $R_{k}$ is the range of variable $k$ in the sample. The division by $R_{k}$ eliminates the differences between variables ranges, producing a value within the range $[0,1]$ and equal weights.

A cluster analysis was obtained from this matrix using the Unweighted Pair Group Mean Average (UPGMA) method. A cophenetic correlation coefficient (CCC) was calculated to validate the clusters generated. A dendrogram was established and the dendrogram cutting point was estimated by the Mojena Method (1977). The relative importance of characters $(\mathrm{S} . \mathrm{j})$ to genetic divergence was done by the method proposed by Singh (1981). All analyses were performed in a statistical genetics computer application - Gene's software (Version 2013.1.5) (CRUZ, 2008).

\section{RESULTS AND DISCUSSION}

\section{Univariate analysis for quantitative descriptors}

After the first cut, there was a significant difference among genotypes at 1\% significance level for two descriptors (NTC and NI); the others did not show significant differences (Table 2). Yet, after the second mowing, there was variation among genotypes, for six of them at $1 \%$, for one at $5 \%$ and for another had no significance (Table 2). Therefore, in general, descriptors were effective in discriminating the genotypes. We can also infer a genetic variability among the genotypes, indicating thus further successful selection through breeding programs.

Table 2. Summary of the individual variance analysis of morpho-agronomic descriptors evaluated in 25 accessions and five buffel grass cultivars after first and second cutting.

\begin{tabular}{|c|c|c|c|c|c|c|c|c|c|}
\hline \multicolumn{10}{|c|}{ Mean Square } \\
\hline \multirow[b]{2}{*}{$\begin{array}{l}\text { Source of } \\
\text { variation }\end{array}$} & \multirow[b]{2}{*}{$\mathrm{DF}$} & \multicolumn{2}{|c|}{ NTC } & \multicolumn{2}{|r|}{$\mathrm{PH}$} & \multicolumn{2}{|r|}{ ST } & \multicolumn{2}{|c|}{ LL } \\
\hline & & Cut1 & Cut2 & Cut1 & Cut2 & $\mathrm{Cu}$ & Cut2 & Cut1 & Cut2 \\
\hline Genotypes & 29 & $4511.79 * *$ & $5094.80 * *$ & 242.85 & $655.38 * *$ & 0.9 & 0.68 & 90.33 & $55.01 * *$ \\
\hline Error & 58 & 236.49 & 416.88 & 161.42 & 206.12 & 0.6 & 0.47 & 77.10 & 18.06 \\
\hline Mean & & 81.67 & 58.76 & 126.84 & 95.98 & 3.1 & 2.21 & 41.76 & 28.71 \\
\hline $\mathrm{CV}(\%)$ & & 18.83 & 34.75 & 10.02 & 14.96 & 24.8 & 31.03 & 21.03 & 14.80 \\
\hline \multicolumn{10}{|c|}{ Mean Square } \\
\hline \multirow[b]{2}{*}{$\begin{array}{l}\text { Source of } \\
\text { variation }\end{array}$} & \multirow[b]{2}{*}{ DF } & \multicolumn{2}{|c|}{ LW } & \multicolumn{2}{|c|}{ IL } & \multicolumn{2}{|c|}{ IW } & \multicolumn{2}{|c|}{ NI } \\
\hline & & Cut1 & Cut2 & Cut1 & Cut2 & Cut1 & Cut2 & Cut1 & Cut2 \\
\hline Genotypes & 29 & 4.67 & $1.82 *$ & 4.059 & $5.09 * *$ & 202.97 & $292.89 * *$ & $4058.31 * *$ & $335.50 * *$ \\
\hline Error & 58 & 3.47 & 0.93 & 2.76 & 1.33 & 29.93 & 4.28 & 256.19 & 8.08 \\
\hline Mean & & 7.03 & 5.20 & 11.77 & 9.00 & 1.62 & 1.48 & 33.92 & 10.74 \\
\hline $\mathrm{CV}(\%)$ & & 26.49 & 18.57 & 14.14 & 12.83 & 33.78 & 13.99 & 47.19 & 26.47 \\
\hline
\end{tabular}

*,** significant at 0.05 and 0.01 probability levels, respectively. CV $(\%)=$ coefficient of variation. NTC - number of tillers per clump; PH - plant height; ST - stem thickness; LL - leaf length; LW - leaf width; IL - inflorescence length; IW - inflorescence width; and number of inflorescences (NI).

In breeding studies, experimental precision is requisite to identify differences between genotypes; and the coefficient of variation $(\mathrm{CV})$ is the most common measure for comparison of experimental precision (SILVA et al., 2011). Although there is no specific CV rating for buffel grass, estimates after first and second cuts, according to Pimentel-Gomes (2009), were classified as medium (from 10 to $20 \%$ ), high (from 20 to 30\%) and very high (>30\%) (Table 2). After the first cut, NTC, PH and IL showed average CVs of $18.83,10.02$ and $14.14 \%$, respectively; yet ST, LL and LW had high CVs of $24.81,21.03$ and $26.49 \%$, respectively. It is noteworthy mention that IW and NI expressed very high CVs in the first cut. After the second cut, PH, LL, LW, IL and IW exhibited average CVs; however, NI presented a CV of 26.47 , which is considered high; the remaining descriptors (ST and NTC) reached a very high CV (Table 2). Similar results were found by Edvan et al. (2011), when evaluating agronomic characteristics of buffel grass under different heights of residue and cuts; thy found CVs ranging from 6.85 to $24.37 \%$.

In the joint analysis, genotype and mowing effects were significant for almost all characteristics (Table 3). These outcomes express genetic variability among genotypes with respect to cutting, and mainly suggest differences in growth rate of each accession at each cutting season.

Moreover, we observed a significant effect of genotype $\mathrm{x}$ environment interaction $(\mathrm{P}<0.01)$ for three descriptors (NTC, IW and NI). Nonetheless, such interaction had no effect for the other descriptors (PH, ST, LL, LW and IL) (Table 3). It is worth noting that all these descriptors are quantitative and, by definition, are environmentally influenced, thus might be controlled by dozens of genes (BORÉM; MIRANDA, 2005). 
L. R. G. P. BRUNO et al.

Table 3. Summary of combined variance analysis of morphoagronomic descriptors evaluated in 25 accessions and five buffel grass cultivars.

\begin{tabular}{lccccccrrr}
\hline \multirow{2}{*}{$\begin{array}{l}\text { Source of } \\
\text { variation }\end{array}$} & \multirow{2}{*}{ DF } & \multicolumn{9}{c}{ Mean Square } \\
\cline { 2 - 10 } & & NTC & PH & ST & LL & LW & IL & IW & NI \\
\hline $\begin{array}{l}\text { Genotypes } \\
\text { Environment }\end{array}$ & 29 & $6427.90^{*}$ & $18023.92^{*}$ & 27.91 & $95.26^{*}$ & $4.37^{*}$ & $6.52^{* *}$ & 301.25 & $3122.47^{* *}$ \\
(Cuts) & $23621.36^{* *}$ & $42849.11^{* *}$ & $41.08^{* *}$ & $7658.39^{* *}$ & $151.25^{* *}$ & $343.90^{* *}$ & 91.02 & $24174.42^{* *}$ \\
G x E & 29 & $3178.70^{* *}$ & 276.71 & 0.68 & 50.09 & 2.13 & 2.63 & $194.60^{* *}$ & $1271.34 * *$ \\
Error & 116 & 326.68 & 183.77 & 0.54 & 47.58 & 2.20 & 2.05 & 17.10 & 132.13 \\
\hline Mean & & 70.21 & 111.40 & 2.69 & 35.23 & 6.16 & 10.38 & 1.55 & 22.33 \\
CV(\%) & & 25.74 & 12.17 & 27.43 & 19.57 & 24.25 & 13.79 & 26.70 & 51.48 \\
S (\%) & & 18.91 & - & - & - & - & - & 13.46 & 91.36 \\
C (\%) & & 81.09 & - & - & - & - & - & 86.54 & 8.64 \\
\hline
\end{tabular}

*** significant at 0.05 and 0.01 probability levels, respectively. $\mathrm{CV}(\%)=$ coefficient of variation. $\mathrm{S}(\%)$ and $\mathrm{C}(\%)=$ Simple and Complex part of interaction. NTC - number of tillers per clump; PH - plant height; ST - stem thickness; LL - leaf length; LW - leaf width; IL - inflorescence length; IW - inflorescence width; and number of inflorescences (NI).

Moreover, we observed a significant effect of genotype $\mathrm{x}$ environment interaction $(\mathrm{P}<0.01)$ for three descriptors (NTC, IW and NI). Nonetheless, such interaction had no effect for the other descriptors (PH, ST, LL, LW and IL) (Table 3). It is worth noting that all these descriptors are quantitative and, by definition, are environmentally influenced, thus might be controlled by dozens of genes (BORÉM; MIRANDA, 2005).

Notwithstanding, five descriptors showed no differences between after-cut evaluations, indicating just one evaluation is required, after one of the cuts. Interactions between accession and environment (cut) can be taken as distinctive performance from one accession to another, whether assessed in more than one environment (BORÉM; MIRANDA, 2005). Thus, for the descriptors that showed significant interaction, it can be inferred that, after the first mowing, the accessions will not behave likely the next cut, i.e., evaluations are necessary after each cutting season.

It can be observed that for descriptors NTC and IW, the complex part of the interaction was well above the simple part (Table 3), highlighting cutting season influence on the differential behavior of accessions. For descriptor NI, however, the simple part of the interaction was higher, indicating that the rank of accessions for this character does not change from one cut to another. The number of tillers per clump and the number of inflorescences can directly influence seed yielding. A large number of seeds is relevant to meet demands of breeding programs in a germplasm bank. In the case of buffel grass, these seeds are obtained by importing or multiplying an introduced germplasm (GRIFFA et al., 2012). Thus, seed production is of fundamental importance, both for breeding and commercial purposes. Seed production is a complex trait highly influenced by many genetic and environmental factors. In several species, seeding can be directly or indirectly affected by several factors, including morpho-agronomic characteristics like plant height, leaf area, leaf length and width, as well as reproduction features, such as the total number of seeds per inflorescence, inflorescence length, inflorescence weight, number of inflorescences per plant, among others (ABBOTT; PISTORALE; ANDRÉS, 2009; GRIFFA et al., 2012.).

Table 4 displays the means and results of Scott-Knott testing for joint analysis of both cuts. For NTC, accession 138 had the highest number (201 tillers). Tillering defines final yield for any species in arid and semi-arid regions. It is one of the main features of forage grasses and ensures persistence after mowing and grazing (SHARMA; VERMA, 1983; MANSOOR et al., 2002). This trait depends not only on genotype, but also on environmental aspects such as nutrition, temperature, light and humidity (MANSOOR et al., 2002). Arshad et al., (2007) reported a highly significant correlation between number of tillers per plant and its fresh weight. Thus, tillering is crucial to ensure good persistence of buffel grass pastures. For $\mathrm{PH}$, accessions 40, 52, 158, 198, 237 and 302 had taller plants averaging from $115.17 \mathrm{~cm}$ to $137.00 \mathrm{~cm}$.

Table 4. Scott-Knott's test of averages of both cuts for the descriptors evaluated in 25 accessions and five buffel grass cultivars.

\begin{tabular}{ccccccccr}
\hline Genotypes & $\begin{array}{c}\text { NTC } \\
\text { (unit) }\end{array}$ & $\begin{array}{c}\text { PH } \\
(\mathrm{cm})\end{array}$ & $\begin{array}{c}\text { ST } \\
(\mathrm{cm})\end{array}$ & $\begin{array}{c}\text { LL } \\
(\mathrm{cm})\end{array}$ & $\begin{array}{c}\text { LW } \\
(\mathrm{mm})\end{array}$ & $\begin{array}{c}\text { IL } \\
(\mathrm{cm})\end{array}$ & $\begin{array}{c}\text { IW } \\
(\mathrm{mm})\end{array}$ & $\begin{array}{c}\text { NI } \\
(\text { unit })\end{array}$ \\
\hline 03 & $103 \mathrm{~b}$ & $118.33 \mathrm{~b}$ & $2.67 \mathrm{a}$ & $30.27 \mathrm{c}$ & $6.17 \mathrm{~b}$ & $9.22 \mathrm{~b}$ & $1.15 \mathrm{a}$ & $64 \mathrm{~b}$ \\
05 & $31 \mathrm{c}$ & $104.17 \mathrm{~b}$ & $3.00 \mathrm{a}$ & $42.07 \mathrm{a}$ & $4.83 \mathrm{~b}$ & $10.50 \mathrm{~b}$ & $1.13 \mathrm{a}$ & $7 \mathrm{~d}$ \\
06 & $89 \mathrm{~b}$ & $107.00 \mathrm{~b}$ & $3.00 \mathrm{a}$ & $34.75 \mathrm{~b}$ & $6.50 \mathrm{~b}$ & $10.37 \mathrm{~b}$ & $1.12 \mathrm{a}$ & $7 \mathrm{~d}$ \\
40 & $54 \mathrm{c}$ & $123.67 \mathrm{a}$ & $2.83 \mathrm{a}$ & $33.50 \mathrm{~b}$ & $4.83 \mathrm{~b}$ & $10.12 \mathrm{~b}$ & $1.35 \mathrm{a}$ & $8 \mathrm{~d}$ \\
\hline
\end{tabular}

${ }^{1}$ Means followed by the same lower case letters in a column do not differ significantly to the level of $5 \%$ probability by the Scott-Knott's test. NTC - number of tillers per clump; PH - plant height; ST - stem thickness; LL - leaf length; LW - leaf width; IL - inflorescence length; IW - inflorescence width; and number of inflorescences (NI). 
L. R. G. P. BRUNO et al.

Table 4. Continuation.

\begin{tabular}{|c|c|c|c|c|c|c|c|c|}
\hline Genotypes & $\begin{array}{l}\text { NTC } \\
\text { (unit) }\end{array}$ & $\begin{array}{c}\mathrm{PH} \\
(\mathrm{cm})\end{array}$ & $\begin{array}{c}\mathrm{ST} \\
(\mathrm{cm})\end{array}$ & $\begin{array}{c}\mathrm{LL} \\
(\mathrm{cm})\end{array}$ & $\begin{array}{c}\mathrm{LW} \\
(\mathrm{mm})\end{array}$ & $\begin{array}{c}\mathrm{IL} \\
(\mathrm{cm})\end{array}$ & $\begin{array}{c}\text { IW } \\
(\mathrm{mm})\end{array}$ & $\begin{array}{c}\text { NI } \\
\text { (unit) }\end{array}$ \\
\hline 52 & $58 \mathrm{c}$ & $125.83 a$ & $3.33 \mathrm{a}$ & $42.83 a$ & $7.00 \mathrm{a}$ & $11.03 \mathrm{a}$ & $1.43 \mathrm{a}$ & $14 d$ \\
\hline 119 & $38 \mathrm{c}$ & $110.00 \mathrm{~b}$ & $2.67 \mathrm{a}$ & $33.53 b$ & $6.00 \mathrm{~b}$ & $9.78 \mathrm{~b}$ & $1.22 \mathrm{a}$ & $18 \mathrm{~d}$ \\
\hline 123 & $84 b$ & $102.75 b$ & $2.50 \mathrm{a}$ & $33.43 b$ & $5.83 b$ & $10.25 b$ & $1.33 \mathrm{a}$ & $37 \mathrm{c}$ \\
\hline 138 & $201 \mathrm{a}$ & $102.08 b$ & $3.33 \mathrm{a}$ & $30.82 \mathrm{c}$ & $5.83 \mathrm{~b}$ & $9.12 b$ & $4.58 \mathrm{a}$ & $120 \mathrm{a}$ \\
\hline 141 & $67 c$ & $105.33 \mathrm{~b}$ & $2.50 \mathrm{a}$ & $37.75 b$ & $6.17 \mathrm{~b}$ & $10.70 \mathrm{a}$ & $1.25 \mathrm{a}$ & $16 \mathrm{~d}$ \\
\hline 198 & $69 c$ & $115.17 \mathrm{a}$ & $3.00 \mathrm{a}$ & $34.95 b$ & $6.33 b$ & $10.07 \mathrm{a}$ & $1.07 \mathrm{a}$ & $8 d$ \\
\hline 237 & $93 b$ & $137.00 \mathrm{a}$ & $3.33 \mathrm{a}$ & $39.50 \mathrm{a}$ & $8.00 \mathrm{a}$ & $11.12 \mathrm{a}$ & $1.60 \mathrm{a}$ & $18 \mathrm{~d}$ \\
\hline 302 & $65 c$ & $119.50 \mathrm{a}$ & $2.50 \mathrm{a}$ & $29.93 c$ & $6.67 \mathrm{a}$ & $9.97 b$ & $1.14 \mathrm{a}$ & $19 d$ \\
\hline 433 & $78 b$ & $94.50 b$ & $2.17 \mathrm{a}$ & $34.00 \mathrm{~b}$ & $4.83 b$ & $9.05 b$ & $1.13 \mathrm{a}$ & $11 d$ \\
\hline 434 & $86 b$ & $104.50 \mathrm{~b}$ & $2.33 \mathrm{a}$ & $29.03 c$ & $5.33 b$ & $12.08 \mathrm{a}$ & $2.82 \mathrm{a}$ & $22 d$ \\
\hline 579 & $94 b$ & $107.00 \mathrm{~b}$ & $3.50 \mathrm{a}$ & $25.85 c$ & $6.17 \mathrm{~b}$ & $8.97 b$ & $1.19 \mathrm{a}$ & $44 c$ \\
\hline 585 & $48 \mathrm{c}$ & $102.83 b$ & $2.00 \mathrm{a}$ & $31.33 c$ & $5.33 b$ & $9.42 \mathrm{~b}$ & $1.23 \mathrm{a}$ & $18 \mathrm{~d}$ \\
\hline 590 & $31 \mathrm{c}$ & $104.50 \mathrm{~b}$ & $2.67 \mathrm{a}$ & $37.83 \mathrm{~b}$ & $6.83^{\mathrm{a}}$ & $11.73 \mathrm{a}$ & $1.37 \mathrm{a}$ & $15 d$ \\
\hline 598 & $96 b$ & $110.33 b$ & $2.00 \mathrm{a}$ & $35.78 \mathrm{~b}$ & $5.83 b$ & $11.02 \mathrm{a}$ & $1.25 \mathrm{a}$ & $24 d$ \\
\hline 603 & $93 b$ & $94.17 \mathrm{~b}$ & $2.17 \mathrm{a}$ & $35.17 \mathrm{~b}$ & $5.50 \mathrm{~b}$ & $8.83 b$ & $1.70 \mathrm{a}$ & $24 d$ \\
\hline 617 & $59 \mathrm{c}$ & $124.50 \mathrm{a}$ & $2.00 \mathrm{a}$ & $40.33 a$ & $5.67 \mathrm{~b}$ & $9.05 b$ & $1.15 \mathrm{a}$ & $4 d$ \\
\hline CPATSA 7754 & $91 b$ & $100.00 \mathrm{~b}$ & $2.67 \mathrm{a}$ & $34.08 \mathrm{~b}$ & $5.17 \mathrm{~b}$ & $10.50 \mathrm{~b}$ & $1.34 \mathrm{a}$ & $42 \mathrm{c}$ \\
\hline Áridus & $49 c$ & $119.83 \mathrm{a}$ & $2.67 \mathrm{a}$ & $36.72 b$ & $7.17 \mathrm{a}$ & $9.85 b$ & $1.28 \mathrm{a}$ & $5 d$ \\
\hline Biloela & $37 \mathrm{c}$ & $125.83 \mathrm{a}$ & $2.50 \mathrm{a}$ & $37.68 b$ & $7.50 \mathrm{a}$ & $10.48 b$ & $1.40 \mathrm{a}$ & $3 d$ \\
\hline Gayndah & $44 c$ & $104.83 b$ & $2.50 \mathrm{a}$ & $34.40 \mathrm{~b}$ & $6.00 \mathrm{~b}$ & $10.10 \mathrm{~b}$ & $1.23 \mathrm{a}$ & $21 d$ \\
\hline
\end{tabular}

${ }^{1}$ Means followed by the same lower case letters in a column do not differ significantly to the level of $5 \%$ probability by the Scott-Knott's test. NTC - number of tillers per clump; PH - plant height; ST - stem thickness; LL - leaf length; LW - leaf width; IL - inflorescence length; IW - inflorescence width; and number of inflorescences (NI).

However, all accessions, except 433 and 603, were considered high according to Oliveira, Silva and Souza (1999), who considered as high plants of $1.0 \mathrm{~m}$ and $1.6 \mathrm{~m}$, using Biloela cultivar as reference. Commercial cultivars can be grouped into tall, medium-height, and short; taller varieties are suitable for heavier soils under intense rainfall, generally used for cattle feeding. These often show welldeveloped rhizomes and, therefore, most resistant to semi-arid conditions, and competitive compared to weeds. Smaller varieties $(<90 \mathrm{~cm})$ are typically grown for sheep and goat pasture, erosion control, being mostly suitable for light-textured soils, less tolerant to flooding, and poorly developed rhizome (MARSHALL; LEWIS; OSTENDORF, 2012). Nonetheless, according to Quiroga et al. (2013), these materials would be advantageous because their smaller size would be beneficial for photosynthate use, perspiration reduction, and hence increased water use efficiency.

There was no significant difference between accessions for ST. Naturally thick buffel grasses accumulate carbohydrates, improving survival in dry periods and regrowth after fires with further onset of rains (BHATTARAI; FOX; GYASI-AGYEI, 2008). LL ranged from $25.85 \mathrm{~cm}$ to $42.83 \mathrm{~cm}$ and LW from $4.83 \mathrm{~mm}$ to $8.17 \mathrm{~mm}$ (Table 4). Likewise, Jorge et al. (2008) reported similar results for buffel grass accessions of the International Livestock Research
Institute of Ethiopia BAG; these authors found LL values from $1.5 \mathrm{~cm}$ to $30.00 \mathrm{~cm}$, and $\mathrm{LW}$ from $3.5 \mathrm{~mm}$ to $8.00 \mathrm{~mm}$. According to the same authors, the ratio $\mathrm{LL} / \mathrm{LW}$ is used as index of leaf size, a trait for species differentiation. Plausibly, larger leaf areas are crucial for yield increase in long-term droughts (MANSOOR et al., 2002).

IL ranged from $8.83 \mathrm{~cm}$ to $12.93 \mathrm{~cm}$, whereas IW showed no significant differences. For NI, we noted a great variation, with plants producing 4 to 120 inflorescences per plant. Larger numbers of inflorescences per plant would probably increase the number of spikelets available for crossing (for crossbred plants) (QUIROGA et al., 2013). Furthermore, according to Griffa et al. (2012), it would also increase seed yield.

\section{Descriptive analyses for qualitative descriptors}

For qualitative descriptors, we observed great variation among accessions. Regarding growth, we registered all patterns, i.e., prostrate growth (accession 433), semi-prostrate (accession 434, 590, 617 and CPATSA 7754), and upright (other accessions). For LC, only two color classes were observed, light and dark green. As for IC, accessions were identified with cream-colored inflorescences $(06,40,52,138,237,541,572$ accession and Áridus cultivar), medium purple $(05,123,141,433,590$, 
598, 617 accession and Gayndah, CPATSA 7754 and Grei cultivars). For SC, all classes were identified, cream $(03,06,52,119,123,141,195,198$, $302,434,541,571,579,585,598,603,617$ accession and Áridus and Biloela cultivars), purple $(05,40,158,237$ accession and Gayndah, CPATSA 7754 and Grei cultivars), and other colors (138 and 433 accession). Qualitative morphological descriptors, together with other descriptors, are used for characterization and identification of cultivars and, therefore, are of great importance.

Regarding leaf hairiness, all accessions showed few trichomes on LH1, with predominance of leaves without trichomes on LH2. For LH3, there was a clear division among accessions, with 17 accessions $(119,123,138,195,198,237,302,433$, 541, 571, 579, 585, 603 accession and CPATSA 7754, Áridus, Gayndah and Grei cultivars) showing trichomes, and the 13 remaining accessions without hairs. The importance of such traits is directly related to animal palatability and forage manual harvesting (SILVA et al., 2009). On the other side, denser hairiness minimizes water loss by transpiration, improving water status under drought conditions, i.e., hairy leaves make some accessions more drought tolerant (MANSOOR et al., 2002).

Multivariate analyses for genetic divergence study among $C$. ciliaris accessions

Based on the cutting point in the dendrogram by the Mojena method (1977), genotypes were separated into three clusters. The first consisted of 23 accessions and three cultivars. The second comprised accessions 433 and 434 plus cultivar CPATSA 7754. Moreover, the third formed only by accession 138 , i.e., it was the most distinctive from all the accessions (Figure 1). The cophenetic correlation coefficient found was 0.81 , denoting good fit between the original distance matrix and the clustering matrix (CRUZ; CARNEIRO; REGAZZI, 2014), therefore, UPGMA showed great reliability to group these genotypes.

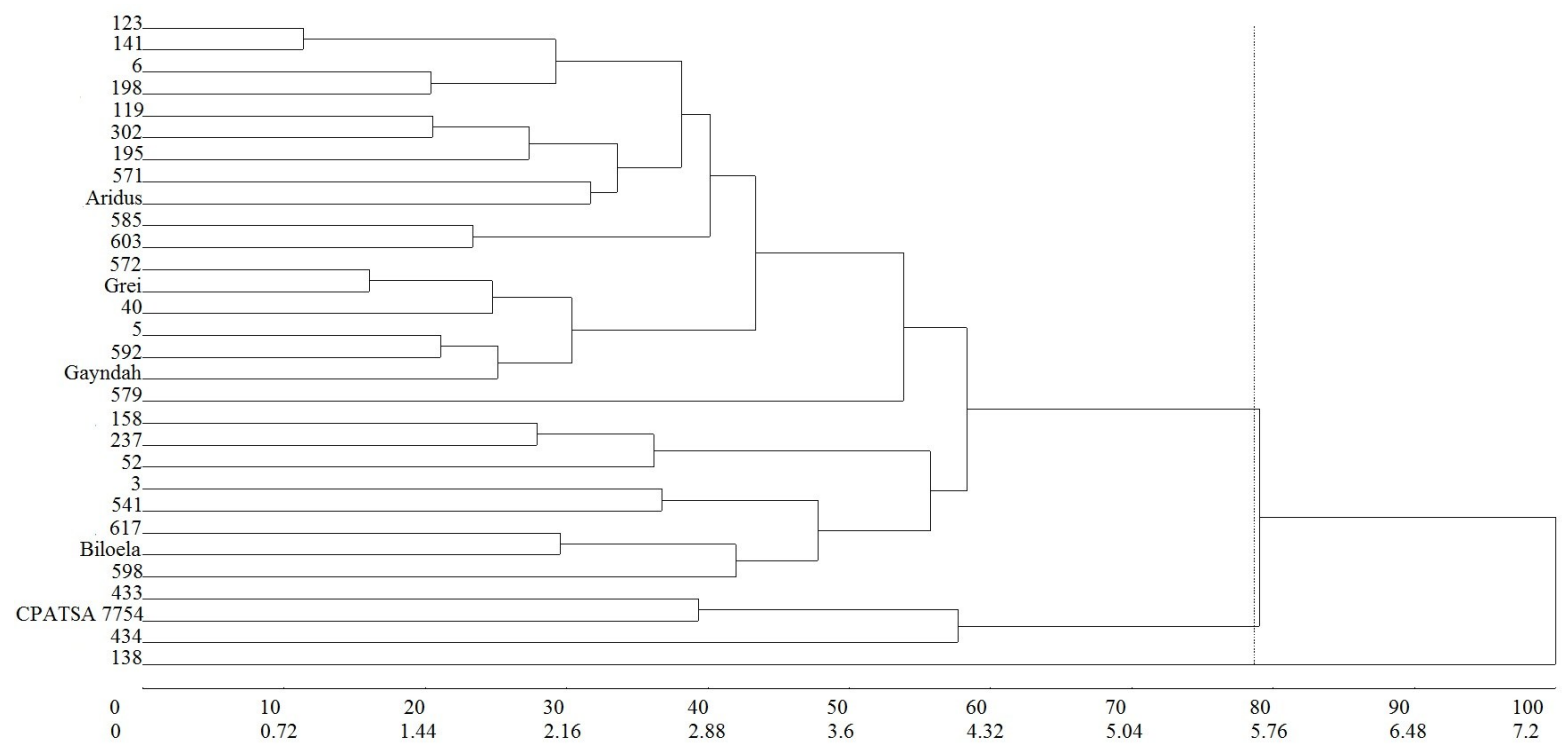

Figure 1. Representative Dendrogram of genetic dissimilarity among 25 accessions and five buffel grass cultivars by the UPGMA method and based on the Gower algorithm (1971), regarding quantitative and qualitative descriptors in two consecutive cuts.

Accessions 433 and 434 have the same geographical origin both were introduced from Australia. Despite being from a distinct origin, cultivar CPATSA 7754 showed NTC, PH, LW and NI similar to both above-mentioned accessions, with HCR equals to accession 434, and CIF and PFO similar to accession 433. In doing so, these similarities would justify the fact they were put into the same group. Access 138 composed a cluster different from all the others, because it had the highest NTC, and the highest NI, as well as a brown $\mathrm{SC}$, which was different from the others.

Although only three clusters were formed, a great variability within the first group, with 23 accessions, could be seen using the Scott-Knott grouping test (Table 4), and the descriptive data analysis. This can be seen because even accessions collected at the same place showed considerable differences, which indicates that there is great variability to be exploited (Table 1 ).

Table 5 shows the relative contributions (S.j) from each of the 15 morpho-agronomic descriptors to the genetic diversity among the 25 studied accessions and the five buffel grass cultivars Interestingly, the variables with the highest relative contributions were NTC, followed by NI, underlining genetic variability for these descriptors among studied accessions. According to these data, the other descriptors had no contribution, or contributed quite little to the genetic diversity study. 
In a morphological characterization study by Arshad et al. (2007) in Pakistan, where climate is similar to the Brazilian semi-arid conditions, i.e., annual average rainfall between $100 \mathrm{~mm}$ and $250 \mathrm{~mm}$ and temperatures above $40{ }^{\circ} \mathrm{C}$, the descriptor which contributed most to the diversity was plant fresh weight, with $33.88 \%$, a feature not evaluated in this study. From the descriptors used in the two studies, PH and NTC contributed with $13.32 \%$ variation in the study presented by Arshad et al. (2007), here, it was $47.22 \%$. It should be noted that this study was carried out in two consecutive cuts, i.e., the statistical analysis was performed with the average of two evaluations, thus having a larger volume of data.

Table 5. Relative contribution (S.j) from each morpho-agronomic descriptor, by the Singh method (1981), to the genetic diversity study among 25 accessions and five buffel grass cultivars.

\begin{tabular}{lrr}
\hline \multicolumn{1}{c}{ Descriptors } & \multicolumn{1}{c}{ S.j } & S.j (\%) \\
\hline Number of tillers per clump (NTC) & 248621.30 & 44.23 \\
Plant height (PH) & 16814.93 & 2.99 \\
Stem thickness (ST) & 3226.39 & 0.57 \\
Leaf length (LL) & 13002.06 & 2.31 \\
Leaf width (LW) & 1726.13 & 0.16 \\
Inflorescence length (IL) & 3610.97 & 0.64 \\
Inflorescence width (IW) & 7161.82 & 1.27 \\
Number of inflorescences (NI) & 230599.42 & 41.02 \\
Growth habit: (GH) & 3681.78 & 0.66 \\
Leaf color (LC) & 41.52 & 0.00 \\
Inflorescence color (IC) & 7817.55 & 1.39 \\
Seed color (SC) & 4699.43 & 1.00 \\
Adaxial leaf hairiness (LH1) & 20686.39 & 3.68 \\
Abaxial leaf hairiness (LH2) & 193.57 & 0.03 \\
Leaf sheath hairiness (LH3) & 261.11 & 0.05 \\
\hline
\end{tabular}

Clearly, the germplasm of this grass species is adapted to a semi-arid climate and, therefore, has great potential for selecting materials resistant to multiple stresses such as drought, salinity and high temperatures, besides characteristics suitable for grazing, and hay or silage production. In view of that, further studies should be carried out to identify accessions for breeding purposes, and thus enhancing the spread of areas grown with this forage.

\section{CONCLUSIONS}

Most of the descriptors had no significant interaction accessions x environments (cuts). A good genetic diversity was observed among the 25 evaluated accessions and the five cultivars. The number of tillers per clump, number of inflorescences and seed color were traits with greater relevance in the clustering of the accessions.

\section{ACKNOWLEDGMENTS}

To CAPES and FACEPE for granting scholarships to the post-graduation students.

\section{REFERENCES}

ABBOTT, L. A.; PISTORALE, S. M.; ANDRÉS, A. Evaluación de los componentes del rendimiento en semilla mediante coeficientes de sendero en poblaciones de agropiro alargado. Agriscientia, Córdoba, v. 26, n. 2, p. 55-62, 2009.

ANTONIO, R. P. et al. Banco Regional de Germoplasma de Mandioca do Semiárido do Nordeste do Brasil. In: SIMPÓSIO DA REDE DE RECURSOS GENÉTICOS VEGETAIS DO NORDESTE, 2., 2015, Fortaleza. Anais... Fortaleza: Embrapa Agroindústria Tropical: Universidade Federal do Ceará, 2015.

ARSHAD, M. A. et al. Morphogenetic variability potential of Cenchrus ciliaris L., from Cholistan desert, Pakistan. Pakistan Journal of Botany, Karachi, v. 39, n. 5, p. 1481-1488, 2007.

BHATTARAI, S. P.; FOX, J.; GYASI-AGYEI, Y. Enhancing buffel grass seed germination by acid treatment for rapid vegetation establishment on railway batters. Journal of Arid Environments, Glen Osmond, v. 72, n. 3, p. 255-262, 2008.

BHERING, M. et al. Características agronômicas do capim-elefante roxo em diferentes idades de corte na Depressão Cuiabana. Revista Brasileira de Saúde e Produção Animal, Salvador, v. 9, n. 3, p. 384-396, 2008.

BORÉM, A.; MIRANDA, G. V. Melhoramento de Plantas. 4. ed. Viçosa, MG: UFV, 2005. 525 p.

BURLE, M. L.; OLIVEIRA, M. S. P. Manual de Curadores de Germoplasma - Vegetal: 
Caracterização Morfológica. Brasília, DF: Embrapa Recursos Genéticos e Biotecnologia; Belém, PA: Embrapa Amazônia Oriental, 2010. 15 p. (Embrapa Recursos Genéticos e Biotecnologia. Documentos, 312; Embrapa Amazônia Oriental, 378).

BURSON, B. L. et al. Genetic diversity among pentaploid buffel grass accessions. Crop Science, Madison, v. 55, n. 4, p. 1637-1645, 2015.

CRUZ, C. D.; CARNEIRO, P. C. S.; REGAZZI, A. $\mathrm{J}$. Modelos biométricos aplicados ao melhoramento genético. 3. ed. Viçosa, MG: UFV, 2014. v. 2, 668 p.

CRUZ, C. D.; CASTOLDI, F. L. Decomposição da interação genótipos x ambientes em partes simples e complexa. Revista Ceres, Viçosa, v. 38, n. 219, p. 422-430, 1991.

CRUZ, C. D. Programa Genes: Diversidade Genética. 1. ed. Viçosa, MG: UFV, 2008. 278 p.

EDVAN, R. L. et al. Características de produção do capim-buffel submetido a intensidades e frequências de corte. Archivos de Zootecnia, Córdoba, v. 60, n. 232, p. 1281-1289, 2011.

GOWER, J. C. A general coefficient of similarity and some of its properties. Biometrics, Arlington, v. 27, n. 3 , p. 857-871, 1971.

GRIFFA, S. et al. Relationship between seed yield and its component characters in Cenchrus spp. Electronic Journal of Plant Breeding, Coimbatore, v. 3, n. 1, p. 701-706, 2012.

JORGE, M. A. B et al. Characterization of a collection of buffel grass (Cenchrus ciliaris). Tropical Grasslands, Cali, v. 42, n. 1, p. 27-39, 2008.

MANSOOR, U. et al. Ecotypic variability for drought resistance in Cenchrus ciliaris L. germplasm from Cholistan desert in Pakistan. International Journal of Agriculture \& Biology, Faisalabad, v. 4, n. 3, p. 392-397, 2002.

MARSHALL, V. M.; LEWIS, M. M.; OSTENDORF, B. Buffel grass (Cenchrus ciliaris) as an invader and threat to biodiversity in arid environments: A review. Journal of Arid Environments, Glen Osmond, v. 78, n. 1, p. 1-12, 2012.

MARTIN, T. G. et al. Buffel grass and climate change: a framework for projecting invasive species distributions when data are scarce. Biological Invasions, Dordrecht, v. 17, n. 11, p. 3197-3210, 2015.
MOJENA R. Hierarchical grouping methods and stopping rules: an evaluation. The Computer Journal, Londres, v. 20, n. 4, p. 359-363, 1977.

MOURA, M. C. C. L. et al. Algoritmo de Gower na estimativa da di-vergência genética em germoplasma de pimenta. Horticultura Brasileira, Brasília, v. 28, n. 2 , p. 155-161, 2010.

OLIVEIRA, M. C.; SILVA, C. M. M. S.; SOUZA, F. B. Capim buffel (Cenchrus ciliaris L.) preservação ex-situ e avaliação aprofundada. In: QUEIROZ, M. A. de; GOEDERT, C. O.; RAMOS, S. R. R. (Eds.). Recursos genéticos e melhoramento de plantas para o Nordeste brasileiro. Petrolina, PE: Embrapa Semiárido; Brasília, DF: Embrapa Recursos Genéticos e Biotecnologia, 1999.

PIMENTEL-GOMES, F. Curso de estatística experimental. 15. ed. Piracicaba, SP: FEALQ, 2009. $451 \mathrm{p}$.

SANTOS, H. G. et al. Sistema brasileiro de classificação de solos. 2. ed. Rio de Janeiro, RJ: Embrapa Solos, 2006. 306 p.

SHARMA, S. K.; VERMA, C. M. Performance of Cenchrus ciliaris L. Strains in an arid rangeland of western Rajastan. Annals of Arid Zone, Jodhpur, v. 22, n. 1, p. 23-27, 1983

SILVA, et al. Recursos genéticos vegetais conservados na Embrapa Semiárido. In: SÁ, I. B.; SILVA, P. C. G. da. (Eds.). Semiárido brasileiro: pesquisa, desenvolvimento e inovação. Petrolina, $\mathrm{PE}$ : Embrapa Semiárido, 2010. cap. 9, p. 282- 284.

SILVA, J. M. et al. Implicações da interação genótipos $\mathrm{x}$ ambientes sobre ganhos com a seleção em meloeiro. Ciência Rural, Santa Maria, v. 41, n. 1, p. 51-56, 2011.

SILVA, S., H. B. et al. Uso de descritores morfológicos e herdabilidade de caracteres em clones de capim-elefante de porte baixo. Revista Brasileira de Zootecnia, Viçosa, v. 38, n. 8, p. 1451-1459, 2009.

SINGH, D. The relative importance of characters affecting genetic divergence. The Indian Journal of Genetic and Plant Breeding, New Delhi, v. 41, n. 2, p. 237-245, 1981 .

QUIROGA, M. et al. Obtaining sexual genotypes for breeding in buffel grass. South African Journal of Botany, Pietermaritzburg, v. 88, n. 1, p. 118-123, 2013. 